\title{
Parking Policy for Transit-Oriented Development: Lessons for Cities, Transit Agencies, and Developers
}

Richard Willson, California State Polytechnic University, Pomona

\begin{abstract}
Parking policy is an important element of transit-oriented development (TOD). It shapes travel behavior, community design, and development economics; it can improve the performance of both rail transit and TOD. This article is based on the study of residential TODs, office TODs, and joint development of transit agency station parking in California. The research includes surveys of travel behavior, stationarea characteristics, parking supply, interviews with real estate developers, and studies of replacement parking issues at joint development sites. Research results show that TOD parking supply and pricing policy seldom are structured to support transit ridership goals. Policy recommendations for improving parking policy for TODs are offered to transit agencies, cities, and developers.
\end{abstract}

\section{Introduction}

Transit-oriented development (TOD) has the potential to address pressing transportation, housing, and environmental issues in U.S. cities (Bernick and Cervero 1997; Cervero, Ferrell, and Murphy 2002; Porter 1997). TOD can reduce vehicle miles traveled (VMT) since residents and workers generally have higher transit mode shares than comparable areas (Lund, Cervero, and Willson 2004; Cervero 1993; Cervero 1994). However, the performance of both rail transit and TOD is 
uneven (Pickrell 1992; Bae 2002). TOD potential has been explained by factors such as system design and siting, development control issues, and public finance (Loukaitou-Sideris and Banerjee 2000; Boarnet and Crane 1998; Willson and Anderson 1993).

Parking policy is an important determinant of travel behavior, regardless of proximity to transit (Shoup and Pickrell 1980; Shoup and Willson 1992; Willson 1992a, b, 1997; Hess 2000). Critics argue that parking is generally oversupplied and underpriced (Shoup 2005). Researchers have called for reforms in minimum parking requirements and the cashing out of parking subsidies (Shoup 1995, 1997, 2005; Willson 1995, 2000). Finally, developers report that parking is one of the most important issues to be resolved in proposing TODs.

Research on TOD policy and parking policy has largely proceeded on parallel tracks. This article connects these themes by examining parking requirements and policies at a series of TOD settings in California and asking whether current parking policies support transit and TOD outcomes. This question is addressed in terms of residential and office TODs, real estate issues, and replacement parking for joint development.

\section{Methodology}

The article draws information and insights from three efforts, summarized in Table 1.

\section{Parking Supply and Policy in Residential TODs}

Twenty-six residential sites were studied in the 2004 Travel Characteristics of Transit-Oriented Development in California (referred to hereafter as the Bay Area Rapid Transit district [BART] study). Fifteen of those sites are grouped into five station areas that have common characteristics (rail technology and station context) and sufficient response rates for statistical validity. The remaining 11 sites are shown in the "other" category, which includes a variety of rail transit modes.

\section{Parking Supply}

Parking supply levels at the California TODs studied are somewhat less than typical levels in the cities in which those TODs are located. The average parking supply per unit is 1.41 , including visitor parking. Parking supply varies from 0.47 to 2.68 spaces per unit with a standard deviation of 0.5 . The ratio of 1.41 spaces per unit means that the square footage of parking exceeds the square footage of living area 
Table 1. Summary of Studies

\begin{tabular}{|c|c|c|}
\hline Study & Rail System Studied & Methodology \\
\hline $\begin{array}{l}\text { Travel Characteristics of } \\
\text { Transit-Oriented Development } \\
\text { in California, Lund, Cervero, } \\
\text { Willson (2004), Caltrans } \\
\text { Statewide Planning Studies } \\
\text { grant, carried out under the } \\
\text { auspices of the Bay Area Rapid } \\
\text { Transit District }\end{array}$ & $\begin{array}{l}\text { Sacramento LRT, Bay Area } \\
\text { Rapid Transit District heavy } \\
\text { rail, Caltrain commuter rail } \\
\text { (northern California), San Jose } \\
\text { VTA light rail, Los Angeles } \\
\text { Metrolink commuter rail, Los } \\
\text { Angeles Blue Line light rail, Los } \\
\text { Angeles Red Line heavy rail, } \\
\text { San Diego Coaster commuter } \\
\text { rail, and San Diego Trolley light } \\
\text { rail }\end{array}$ & $\begin{array}{l}\text { Study of } 36 \text { TODs using mail-back } \\
\text { questionnaires of residents, } \\
\text { employer-distributed worker } \\
\text { questionnaires, studies of site and } \\
\text { context analyses, regional } \\
\text { characteristics, and parking } \\
\text { policies. Study sites were non- } \\
\text { CBD TOD locations within one- } \\
\text { half mile of a transit station }\end{array}$ \\
\hline $\begin{array}{l}\text { The Pasadena Gold Line: } \\
\text { Development Strategies, } \\
\text { Location Decisions and Travel } \\
\text { Characteristics along a New } \\
\text { Rail Line in the Los Angeles } \\
\text { Region, Lund and Willson } \\
\text { (2005), Mineta } \\
\text { Transportation Institute, San } \\
\text { Jose State University }\end{array}$ & $\begin{array}{l}\text { Los Angeles-Pasadena Gold } \\
\text { Line light rail }\end{array}$ & $\begin{array}{l}\text { Study of } 37 \text { residential TODs along } \\
\text { the Gold Line. Data collected using } \\
\text { mail-back questionnaires of } \\
\text { residents, site and context } \\
\text { analyses, measures of regional } \\
\text { land-use and transportation } \\
\text { characteristics, and interviews of } \\
\text { developers and property owners }\end{array}$ \\
\hline $\begin{array}{l}\text { Replacement Parking for Joint } \\
\text { Development: } \\
\text { Access Policy Methodology } \\
\text { BART/Willson, (2005) }\end{array}$ & $\begin{array}{l}\text { Bay Area Rapid Transit District } \\
\text { heavy rail }\end{array}$ & $\begin{array}{l}\text { Principles and methodology for } \\
\text { determining replacement parking. } \\
\text { Four case study stations }\end{array}$ \\
\hline
\end{tabular}

unless the unit is greater than 493 square feet. A 1,000 square foot unit would require an additional building area amount of about 50 percent to accommodate parking. Table 2 summarizes the results.

Table 2 also shows the reported transit shares for journey-to-work trips and all "main" trips. For the five station groupings, there is a 0.98 correlation between transit mode share and percent of households with less than one vehicle per driver. Lower car availability means greater transit use. However, the correlation between parking supply (spaces per unit) and the journey-to-work transit share is -0.26 . This is the expected sign (greater parking supply is associated with less transit use) but is not statistically significant.

Why was there not a statistically significant relationship between parking supply and transit share? First, and most importantly, most units had more than one space per unit. Most projects had plentiful supply. Parking was so generously supplied that the sensitivity of mode to parking supply could not be tested. Second, this analysis did not consider the availability of on-street parking as an alternative. 
Table 2. Parking Supply and Pricing in Residential Buildings $(\mathbf{n}=\mathbf{2 6})$

\begin{tabular}{|l|c|c|c|}
\hline & $\begin{array}{c}\text { Percent } \\
\text { Households with } \\
<\mathbf{1}\end{array}$ & $\begin{array}{c}\text { Parking Spaces } \\
\text { per Unit }\end{array}$ & $\begin{array}{c}\text { Transit Share (\%) } \\
\text { Jehicle/Driver }\end{array}$ \\
\hline $\begin{array}{l}\text { BART: Pleasant Hill trips* } \\
\text { (4) }\end{array}$ & 1.08 & 24.0 & $20.8 / 19.2$ \\
\hline $\begin{array}{l}\text { BART: So. Alameda } \\
\text { County (4) }\end{array}$ & 1.31 & 30.6 & $29.9 / 27.4$ \\
\hline $\begin{array}{l}\text { LA Blue Line: Long } \\
\text { Beach (2) }\end{array}$ & 1.25 & 16.7 & $2.8 / 2.2$ \\
\hline $\begin{array}{l}\text { SD Trolley: Mission } \\
\text { Valley (2) }\end{array}$ & 1.92 & 21.5 & $10.5 / 11.3$ \\
\hline $\begin{array}{l}\text { Caltrain: Commuter } \\
\text { Rail (3) }\end{array}$ & 1.35 & 21.6 & $11.0 / 11.3$ \\
\hline Other (11) & 1.42 & 39.2 & $28.0 / 25.4$ \\
\hline Average (unweighted) & 1.41 & 26.4 & $22.4 / 20.7$ \\
\hline
\end{tabular}

* The "All trips" category asked respondents to report on three main trips taken that day. It is not based on a full travel diary inventory.

Available on-street parking might make parking supply a weaker influence on mode choice.

The lack of a statistically significant relationship between supply and mode choice is of interest to planning regulation and development practices. Looking at the relationship in the other causal direction, projects with higher levels of transit use did not have statistically significant lower parking supplies. In other words, those projects oversupplied parking for the level of transit use, either as the result of city codes or developer/investor preferences.

Oversupplying parking in TODs uses scarce land for which there are better community uses. It also drives up occupancy costs (since parking is bundled with rent payments) and/or lowers return on investment. It encourages developers to build larger residential units so that they can amortize the cost of required parking across a greater per unit rent stream (Hitchcock 1999; Litman 1998), further harming housing affordability. Finally, unused spaces in residential projects are rarely shared with other uses because of the desire to control access to the parking. Excess residential parking rarely contributes to a district area parking supply. 


\section{Parking Pricing}

Results from the BART survey indicate that apartment managers "bundle" parking charges with rent, providing free parking along with the rental unit. None of the residential projects had a separate charge for parking, independent of the lease rate. Bundled parking is problematic in all locations, but is particularly problematic for TODs. First, tenants receive no market signal about the cost of providing parking and are likely to have higher automobile ownership for that reason. Developers have no information on tenants' willingness to pay for parking. In the location where the greatest investment in transit has been made, residents perceive parking to be "free."

Because parking was bundled in all the cases studied, it is impossible to test the sensitivity of TOD residents to home-based parking charges. The cost of providing this parking is $\$ 16,920$ per unit (estimated at the 1.41 space per unit ratio and a per space cost of $\$ 12,000)$. This cost is reflected in either higher rents or a reduction in land value.

As reported in the literature (Willson 1992a), worksite parking policies have a strong influence on the level of transit use among TOD residents. The BART study found that free parking at work is a significant predictor in the binomial logit model developed for that study. It is likely that the combination of parking charges at the residence and the workplace would have an even larger impact on increasing transit use.

\section{Parking Supply and Policy in Office TODs Parking Supply}

Table 3 indicates that the TODs studied had an office parking supply that is generally lower than the 4.0 spaces per 1,000 square feet convention for office projects. However, since the average utilization of office projects nationwide is 2.84 occupied spaces per 1,000 square feet gross floor area (Institute of Transportation Engineers 2004), parking is still generously supplied in these projects. The projects studied averaged well over one space per reported worker. It is important to note that most of these projects were built prior to the 1990s, when workplace parking requirements were not an important public policy issue. Therefore, we should not expect to see an anticipation of transit access effect on parking demand in older projects. 
Table 3. Parking Supply in Office Buildings $(n=10)$

\begin{tabular}{|l|c|c|c|c|} 
& $\begin{array}{c}\text { Date Project } \\
\text { Built }\end{array}$ & $\begin{array}{c}\text { Spaces per } \\
\mathbf{1 , 0 0 0} \text { Square } \\
\text { Feet }\end{array}$ & $\begin{array}{c}\text { Spaces per } \\
\text { Worker }\end{array}$ & Transit Share \\
\hline BART: Berkeley (1) & 1971 & 4.0 & 1.6 & $38.5 \%$ \\
\hline $\begin{array}{l}\text { BART: Walnut } \\
\text { Creek/Freemont (2) }\end{array}$ & 1985,1989 & 2.9 & 1.4 & $19.2 \%$ \\
\hline $\begin{array}{l}\text { LA Red Line: Hollywood, } \\
\text { North Hollywood (2) }\end{array}$ & 1921,1987 & 2.6 & 1.4 & $7.5 \%$ \\
\hline $\begin{array}{l}\text { SD Trolley: Mission Valley } \\
\text { (1) }\end{array}$ & 1995 & 4.0 & 1.1 & $2.9 \%$ \\
\hline Sacramento LRT (2) & $\begin{array}{c}1989, \text { not } \\
\text { known }\end{array}$ & 3.6 & 1.0 & $22.8 \%$ \\
\hline Metrolink: Anaheim (1) & 1988 & 3.9 & 1.6 & $13.0 \%$ \\
\hline Other (1) & Not known & 1.7 & 1.4 & $13.0 \%$ \\
\hline Average (unweighted) & & $\mathbf{3 . 1}$ & $\mathbf{1 . 3}$ & $\mathbf{1 6 . 3 \%}$ \\
\hline
\end{tabular}

The project level groupings shown in Table 3 did not produce a positive and statistically significant correlation between supply and transit mode share. Every project had at least one space per worker, so there was no availability constraint that would affect supply. The BART project was an outlier in that it had the highest transit share and high parking supply (the project was built in 1971).

\section{Parking Charges in Leases and to Workers}

Arrangements for office parking charges varied more than those observed for residential units. In some situations, the cost of providing parking was bundled into lease payments, while in other situations there was a direct pass-through of parking charges to employees. However, many TOD employers offered their employees free parking. Table 4 summarizes the BART TOD study data according to station groupings. Several measures of parking cost are provided. The second column provides the market parking price determined in site research, which average $\$ 49$ per month at the 10 sites. There is a 0.73 correlation between market price and transit share, indicating that higher parking prices are associated with a higher transit share. Of course, market price is not a reliable indicator of the price commuters actually pay, since it is common practice for employers to subsidize parking (Shoup 1997).

The third column lists the parking pricing policy reported by the property owners. This generally indicates subsidy policy, but may not reflect variation among employers or variation in benefits offered to different classes of employees. 
Table 4. Parking Prices, Terms, and Transit Share

\begin{tabular}{|l|c|c|c|c|c|}
\hline & $\begin{array}{c}\text { Monthly } \\
\text { Market } \\
\text { Parking Price }\end{array}$ & $\begin{array}{c}\text { Parking } \\
\text { Payment } \\
\text { (from Site } \\
\text { Survey) }\end{array}$ & $\begin{array}{c}\text { Daily } \\
\text { Reported } \\
\text { Price Paid (by } \\
\text { Those Who } \\
\text { Drove) }\end{array}$ & $\begin{array}{c}\text { Employer } \\
\text { Provides Free } \\
\text { Parking } \\
\text { (Employee } \\
\text { Response) }\end{array}$ & Transit Share \\
\hline $\begin{array}{l}\text { BART: Berkeley } \\
(1)\end{array}$ & $\$ 125$ & $\begin{array}{c}\text { Paid by } \\
\text { worker }\end{array}$ & $\$ 4.94$ & $33.3 \%$ & $38.5 \%$ \\
\hline $\begin{array}{l}\text { BART: Walnut } \\
\text { Creek/Freemont } \\
(2)\end{array}$ & $\$ 34$ & $\begin{array}{c}\text { Employer } \\
\text { invoiced, free }\end{array}$ & $\$ 2.50$ & $76.5 \%$ & $19.2 \%$ \\
\hline $\begin{array}{l}\text { LA Red Line: } \\
\text { Hollywood (2) }\end{array}$ & $\$ 85$ & $\begin{array}{c}\text { Bundled in } \\
\text { tenant leases }\end{array}$ & $\$ 3.33$ & $89.2 \%$ & $7.5 \%$ \\
\hline $\begin{array}{l}\text { SD Trolley: } \\
\text { Mission Valley } \\
(1)\end{array}$ & $\$ 0$ & Free & $\$ 3.00$ & $82.9 \%$ & $2.9 \%$ \\
\hline $\begin{array}{l}\text { Sacramento LRT } \\
(2)\end{array}$ & $\$ 50$ & $\begin{array}{c}\text { Paid by } \\
\text { worker, free }\end{array}$ & $\$ 4.71$ & $24.6 \%$ & $22.8 \%$ \\
\hline $\begin{array}{l}\text { Metrolink: } \\
\text { Anaheim (1) }\end{array}$ & $\$ 25$ & $\begin{array}{c}\text { Bundled in } \\
\text { tenant leases }\end{array}$ & $\$ 0$ & $86.5 \%$ & $13.0 \%$ \\
\hline $\begin{array}{l}\text { San Jose VTA: } \\
\text { Baypointe (1) }\end{array}$ & $\$ 0$ & Free & $\$ 0$ & $100 \%$ & $9.5 \%$ \\
\hline $\begin{array}{l}\text { Average } \\
\text { (unweighted) }\end{array}$ & $\$ 49$ & & $\$ 2.64$ & $70.6 \%$ & $\mathbf{1 6 . 3 \%}$ \\
\hline
\end{tabular}

The fourth column shows the reported price paid by those who drove. Because respondents who do not drive often do not know what their parking costs would be, the survey instrument was not able to collect reliable individual level data on the price of parking for all commuters. We cannot assume that transit users faced the same parking price as those who drove (either due to differential policies among employee classes or different choices about parking location).

The fifth column indicates the percentage of employees who said that their employer offers free parking, which averaged 70.6 percent. The correlation between the percentage reporting free parking and transit use is -0.80 , indicating that free parking undermines that transit access advantages that TODs provide. Parking charges are a source of potentially large gains in station area ridership.

Among the office sites surveyed, the California Department of Conservation building in downtown Sacramento had the highest transit share-41.3 percent. This is achieved on a light rail system that is relatively new and limited in scope. Parking is $\$ 100$ per month, with a reserved space costing $\$ 130$ per month. There are other transit-supporting factors present as well-the project is located in a dense, 
mixed-use downtown with high employment density (37.6 workers per acre) and is within 165 feet of a light rail station.

\section{Real Estate Aspects of Parking Supply and Policy Parking Supply}

Research on parking utilization and pricing often concludes that conventional practice results in the oversupply and underpricing of parking (Willson 1995, 2000). Furthermore, parking policies often favor automobile access and automobile-oriented land-use planning in a way that has a self-reinforcing effect of discouraging transit use. Planners often point to developer and lender "rules of thumb" for supply (e.g., 1.0 space per bedroom for residential and 4.0 spaces per 1,000 square feet for offices) and leasing arrangements (bundling the cost of parking with rent) as part of the problem. Eleven telephone interviews were conducted with developers working on residential projects in the Los Angeles-Pasadena Gold Line TOD study in July/August 2004 to better understand their perspectives and practices (Lund and Willson 2005).

Although most developers expected light rail proximity to influence the travel behavior of their tenants, they were cautious about predicting effects on parking demand. Most developers did not systematically collect data on rail ridership, mode choice, or levels of car ownership. An intuitive sense that rail and TOD were well suited seemed to drive their decision-making. Importantly, the rail/TOD connection also facilitated the process of obtaining development entitlements, making it easier for developers to justify additional density to the community and decision-making bodies.

The interviews did suggest that parking practice is changing, albeit slowly, with some developers reducing the number of free parking spaces provided with a unit, and renting additional spaces at a market price. The change is most pronounced in downtown areas, where parking is being decoupled from rent or purchase price and where some cities have eliminated traditional minimum parking requirements.

Jurisdictions in the Gold Line corridor provide relief from conventional parking requirements through TOD specific plan provisions and/or variances. In one case, a developer reported that the City of Pasadena requested that the developer seek a variance to their own code to reduce parking supply to 1.5 spaces per unit. In another Pasadena case, the developer did not seek to build below code require- 
ments but exceeded them, building 1.7 spaces per unit despite the fact that the underground spaces cost an estimated $\$ 30,000$ per space. Explanations for this approach include the fact that the Gold line was untested when the parking supply decisions were being made and that the income profile of the expected residents was higher than the average apartment unit. Remaining prominent in developers' and investors' minds is the perception of market risk associated with a project being undersupplied with parking in comparison to its competitors.

Interviews suggest that the development community is becoming more favorable to rationalizing parking supply and using unbundling strategies. However, developers need market-specific experience and examples before they consider meaningful reductions in parking supply. Leasing agents must be convinced that they can market projects with less parking and/or unbundled parking. This must be supported by project planning, design, construction, and sales processes that are better integrated in terms of parking. Developers indicated that projects get locked into parking ratios early on in ways that inhibit innovations in parking management and pricing.

Because parking is so expensive to provide, parking ratios and pricing policies strongly influence developers' ability to provide affordable housing. Most of the projects surveyed provided little affordable housing, despite this issue being high on the priority list of many cities and regional agencies. TODs' location efficiency should be carefully worked into minimum parking requirements and other parking policies to ensure that savings on parking are realized and are passed on to residents.

\section{Impact of Parking on Joint Development on Transit Agency Land}

The case of TOD construction on transit district land presents special parking challenges. Unlike office and residential TODs, transit station area parking is frequently fully utilized during peak hours. In the Bay Area, BART has long had a practice of requiring one-for-one replacement of station-area parking. Developers were required to build to city code requirements for the TOD and replace all surface commuter spaces for BART patrons. The reason for this practice was to ensure that existing patrons were not lost because of a reduction of commuter parking. There are some problems with this practice. For example:

- It is a financial and site design impediment to joint development projects.

- Private and/or public resources are not available to fund replacement parking. 
- The 1:1 replacement approach focuses on only one access mode (those who drive and park).

- Parking generates less net return than development.

BART has adopted a broader approach to access and replacement parking, aligned with the following principles: support ridership; improve the agency's fiscal condition; reduce the share of station access by those who drive alone and park; support the management of system and station capacity; and support the broader goals of the transit agency, local cities, and regional entities.

A methodology was developed to deal with the replacement parking issue. It addresses riders potentially lost due to space reductions, plus riders gained from joint development (Willson 2005). New attention is given to the fiscal impacts of alternatives to 1:1 replacement. The following categories are considered in terms of revenue gains or losses:

- fare revenue (net ridership gain or loss, considering new riders from the joint development, any lost riders associated with reduced commuter parking supply, impact of parking charge programs and other access programs);

- parking revenue associated with new parking charge programs (net of collection costs, plus amortized equipment cost);

- parking operating costs (associated with a change from surface to structure spaces);

- transit system operating costs (related to greater ridership, changes in peaking of ridership, etc.);

- ground rent from the joint development; and

- grant revenue and revenue from potential partnerships with other parties (e.g., cities, transit operators, regional agencies, etc.).

The revenue bottom line is considered along with other key objectives listed above to generate a matrix display of the performance of alternative joint development/ replacement parking scenarios. BART has conducted tests with the replacement parking methodology on four stations and has adopted this methodology. The key initial findings suggest the following:

- Requiring less than 1:1 replacement of commuter parking produces gains in ridership and revenues and fulfills most BART goals as compared to requiring full replacement parking. Development feasibility improves as replacement parking requirements are relaxed. 
- Aggressive development scenarios that include no replacement of parking, the institution of parking charges, and more intensive development produce the net greatest benefits, although less ridership gain them moderate alternatives. These types of scenarios generate more than $\$ 1$ million per year, per station, in net proceeds for BART, funds that are ongoing and unrestricted in use. In contrast, 1:1 replacement of commuter parking, combined with lower density joint development and no use of parking charges, produce negative results for BART.

- The right decision about replacement parking is dependent on station context. For example, parking at end-of-the-line stations provides an important source of ridership, while mid-line stations are much less dependent on parking for their ridership. The availability of alterative access modes is critical as well.

- A wide variety of alternatives for replacement parking are available, including relocating it off site or at an underused station, or not fully replacing it and instead funding alternative access improvements.

\section{Conclusions and Policy Recommendations}

Current parking supply and pricing policies do not support the transit objectives of TOD. Although planners often emphasize urban design qualities, streetscapes, feeder bus services, and the like, they should not ignore parking policy. Initiatives in this area should include local governments, transit agencies, and developers. Now that transit systems are maturing and the market for TOD has strengthened, local planners should team up with transit agencies and developers to ensure that parking policies support high transit ridership.

The process of adjusting parking supply and policies from status-quo, parkingfocused approaches is different in each community. Some communities embrace these changes, while others doubt the impact of rail transit on travel behavior and automobile ownership. If TODs are transit adjacent but not functionally related, developers and cities have justification in being cautious about reducing parking supply. Fortunately, the growing body of evidence about the types of circumstances where TODs substantively change mode choice and automobile ownership will help communities assess their own conditions. It is also important to recognize that many existing regulations and building practices have the effect 
of creating a self-fulfilling prophecy-high parking requirements mean low or zero parking prices, which undermine the realization of full transit or TOD benefits.

The following sections provide a series of suggestions for cities, transit agencies, and developers, based on the research reviewed above.

\section{Suggestions for Cities}

- Adopt demand-based, locally-calibrated TOD parking requirements that reflect expected transit shares and automobile ownership in the particular TOD under consideration. The data provided in this article and Lund, Cervero and Willson's (2004) report will soon be supplemented by data on TOD parking generation from other studies (Institute of Transportation Engineers, California TOD studies, etc.). Alternatively, cities can deregulate parking in transit districts if they properly manage on-street parking. The City of Los Angeles, for example, recently had success in partially deregulating parking in its Adaptive Reuse Ordinance. This approach puts decisions about parking supply for housing and offices in the hands of developers, who assess market demand and prices in determining the best use of capital.

- Adopt a district-based approach to assessing parking demand and require shared parking. Create urban design standards that make the sharing of parking resources possible. Use in-lieu provisions to create district-based parking facilities. Find ways to reduce developers' risks of undersupplying parking on a particular project through shared parking and district parking resources.

- Pursue partnerships with transit agencies for shared station-area parking planning and supply, and use legal arrangements, such as joint powers authorities, to implement multiagency and multiproperty owner strategies.

- Encourage/require unbundling of parking charges from space leases in agreements for residential and office developments.

- Encourage/require employer tenants to cash-out parking in office developments.

- Actively manage on-street parking to control overspill parking and encourage rapid turnover of on-street spaces. Prioritize on-street parking for short-term, visitor parking. Show community groups how parking management can manage demand and provide a revenue stream for neighborhood improvements. 
- Consider the economic impact of parking requirements on housing affordability in station areas.

\section{Suggestions for Transit Agencies}

- Design stations and station-area parking in a way that places housing and mixed-use development in convenient proximity to stations. Alignment and station location planning should consider how parking affects the walkability of the station vicinity and possibilities for shared parking.

- Convert park-and-ride surface lots to TODs with less than full replacement of parking. Consider development schemes that coordinate multiple property owners and optimize land allocation. Assess the degree to which replacing parking with TOD reduces the demand peaks on the transit system.

- Partner with local jurisdictions in developing parking requirements and policies that support transit use, adopting an access perspective rather than a parking-supply perspective.

- Partner with local jurisdictions, employers, and other transit agencies to support growth in the capacity of nonautomobile station access modes, such as feeder bus services, bicycle, and pedestrian facilities, etc.

\section{Suggestions for Developers}

- Align parking supply with actual demand when the parking is priced at its true cost. Supply parking to average demand, not peak demand, using shared parking to accommodate demand peaks. Design projects so shared parking can be realized and modified with ease.

- Unbundle parking from space rent or sales price.

- Pursue shared parking opportunities, in terms of legal agreements and design features.

- Involve project architects, market researchers, and leasing agents in early conversations about ways to alter conventional parking supply and leasing practices.

Parking in TOD provides a critical connection between design characteristics and transportation behavior, yet stakeholders have been slow to address this issue. Careful design of both parking supply and policy holds great promise to improve the outcomes of TOD. These transit districts provide just the ridership characteristics that rail transit operators seek, with a high transit share, multiple trip purposes, multidirectional trips, and a broad time-of-day distribution. 


\section{References}

Bae, C. 2002. Orenco Station, Portland, Oregon: A successful transit oriented development experiment? Transportation Quarterly 56 (3), Summer.

Bernick, M., and R. Cervero. 1997. Transit villages for the 21st century. New York: McGraw-Hill.

Boarnet, M., and R. Crane. 1998. Public finance and transit-oriented planning: New evidence from southern California. Journal of Planning Education and Research 17 (3): 206-219.

Cervero, R. 1993. Ridership impacts of transit-focused development in California 45. Berkeley, CA: Institute of Urban and Regional Development, University of California.

Cervero, R. 1994. Transit-based housing in California: Evidence on ridership impacts. Transport Policy 3: 17-183.

Cervero, R., C. Ferrell, and S. Murphy. 2002. Transit-oriented development and joint development in the United States: A literature review. TCRP Research Results Digest 52. Washington, DC: National Research Council.

Hess, D. B. 2000. The effect of free parking on commuter mode choice: Evidence from travel diary data. Paper presented at the 42nd Annual Conference of the Association of Collegiate Schools of Planning, Atlanta.

Hitchcock, M. 1999. Parking in the Bay Area. California Planner. November/ December: 8-9.

Institute of Transportation Engineers. 2004. Parking generation, 3rd ed. Washington DC.

Litman, Todd. 1998. Parking requirement impact on housing affordability. Victoria, British Columbia: Victoria Transport Policy Institute.

Loukaitou-Sideris, A., and T. Banerjee. 2000. The Blue Line blues: Why the vision of transit village may not materialize despite impressive growth in transit ridership. Journal of Urban Design 5 (2): 101-125.

Lund, H., R. Cervero, and R. Willson. 2004. Travel characteristics of transit-oriented development in California. Oakland, CA: Bay Area Rapid Transit District. 
Lund, H., and R. Willson. 2005. The Pasadena Gold Line: Development strategies, location decisions and travel characteristics along a new rail line in the Los Angeles region. San Jose, CA: Mineta Transportation Institute.

Pickrell, D. 1992. A desire named Streetcar: Fantasy and fact in rail transit planning. Journal of the American Planning Association 58: 158-176.

Porter, D. 1997. Transit-focused development. TCRP Synthesis 20. Washington, DC: Transit Cooperative Research Program, National Research Council.

Shoup, D. 2005. The high cost of free parking. Chicago: APA Planners Press.

Shoup, D. 1997. Evaluating the effects of cashing out employer-paid parking: Eight case studies. Transport Policy 4 (4): 201-216.

Shoup, D. 1995. An opportunity to reduce minimum parking requirements. Journal of the American Planning Association 61: 14-28.

Shoup D., and R. Willson. 1992. Employer-paid parking: The problem and a proposed solution. Transportation Quarterly 46: 169-192.

Shoup D., and D. Pickrell. 1980. Free parking as a transportation problem. Washington, DC: U.S. Department of Transportation.

Willson, R. 2005. Replacement parking for joint development: An access policy methodology. Oakland, CA: Bay Area Rapid Transit District. Accessed at http://www.bart.gov/about/planning/station.asp.

Willson, R. 2000. Reading between the regulations: Parking requirements, planners' perspectives and transit. Journal of Public Transportation 3: 111-128.

Willson, R. 1997. Parking pricing without tears: Trip reduction programs. Transportation Quarterly 51: 79-90.

Willson, R. 1995. Suburban parking requirements: A tacit policy for automobile use and sprawl. Journal of the American Planning Association 66: 29-42.

Willson, R. 1992a. Estimating the travel and parking demand effects of employerpaid parking. Regional Science and Urban Economics 22: 133-145.

Willson, R. 1992b. Suburban parking economics and policy: Cases studies of office worksites in southern California. Report FTA-CA-11-0036-92-1. Washington, DC: U.S. Department of Transportation. 
Willson, R., and J. Anderson. 1993. Planning for transit-oriented development in San Diego and Vancouver, British Columbia. Paper presented at the 35th Annual Meeting of the Association of Collegiate Schools of Planning, Philadelphia, Pennsylvania.

\section{About the Author}

RICHARD WiLLSON (rwwillson@csupomona.edu) is a professor and chair of the Department of Urban and Regional Planning at California State Polytechnic University, Pomona. Dr. Willson's research in transportation planning addresses landuse transportation relationships, travel demand management, and parking policy. $\mathrm{He}$ also consults with regional and local transportation agencies such as the Bay Area Rapid Transit District. Dr. Willson holds a Ph.D. in urban planning from the University of California, Los Angeles and is a member of the American Institute of Certified Planners. 